\title{
EFEKTIVITAS DAUN PETAI CINA (Leucaena leucocephala)DAN DAUN JARAK PAGAR (Jatropha curcas) TERHADAPPROSES PENYEMBUHAN LUKA BAKAR GRADE IIPADA TIKUS PUTIH (Rattus norvegicus)
}

\author{
Siti Ni'matur Rohmah ${ }^{1}$, Dina Zakiyyatul Fuadah ${ }^{2}$, Pria Wahyu Romadhon Girianto ${ }^{3}$ \\ ${ }^{1,2,3}$ S1 Keperawatan STIKES Karya Husada Kediri
}

\begin{abstract}
ABSTRAK
Luka bakar merupakan jenis trauma dengan morbiditas dan mortalitas tinggi.Jika tidak diatasi menimbulkan infeksi respirasi, infeksi ginjal, infeksi kardiovaskuler, infeksi hematologi, dan infeksi neurologi.Perawatan terbaik dan optimal dalam masalah ini, dapat menggunakan terapi komplementer yang mempercepat penyembuhan luka bakar.Alternatif terapi komplementer ini menggunakan daun petai cina dan daun jarak pagar. Penelitian bertujuan untuk mengetahui efektivitas daun petai cina (Leucaena leucocephala) dan daun jarak pagar (Jatropha curcas) terhadap proses penyembuhan luka bakar grade II pada tikus putih (Rattus norvegicus).Jenis penelitian True Eksperimen dengan metode Comparative Design.Sampel terdiri dari 18 tikus putih dibagi 2 kelompok perlakuan, teknik sampling menggunakan random sampling. Variabel independen dalam penelitian adalah perawatan dengan lumatan daun petai cina dan lumatan daun jarak pagar sedangkan variabel dependen adalah proses penyembuhan luka bakar grade II. Analisis statistik menggunakan Independent $t$-test dengan $\alpha=0,01$. Hasil penelitian menunjukkan $\rho<0,0001$ sehingga ada perbedaan efektivitas antara daun petai cina dan daun jarak pagar terhadap luka bakar grade II dengan selisih 2 hari, lebih cepat menggunakan daun petai cina. Dengan demikian, daun petai cina lebih efektif dalam penyembuhan luka bakar grade I/ dilihat dari kandungan, adaptasi terhadap lingkungan, pengolahan, efisiensi, keterjangkauan dan ketersediaan di masyarakat, sehingga dapat dimanfaatkan sebagai terapi komplementer.
\end{abstract}

Kata Kunci: Efektivitas, Daun Petai Cina, Daun Jarak Pagar, Penyembuhan Luka Bakar Grade II

\begin{abstract}
The burns is a type of trauma with high morbidity and mortality. If isn't overcome, it can cause respiratory infection, kidney infection, cardiovascular infection, hematological infection, and neurological infection. The best and optimal care to solve this problem that is complementary therapy that accelerate the healing of burn. The alternative of this complementary therapy by using Leucaena's leaves and Jatropha's leaves. The aims, of the research was to determined the effectivity of Leucaena's leaves (Leucaena leucocephala) and Jatropha's leaves (Jatropha curcas) toward the healing process of burn grade II on white rat (Rattus norvegicus). Design were used the True Experiment with comparative used random sampling technique, amount of sample 18 rats, divided into 2 treatment groups. The independent variable was treatment with Leucena's leaves and Jatropha's leaves, the dependent variable was the healing process of burn grade II. Statistical analysis were used Independent $t$-test with $\alpha=0,01$. The results showed $\rho<0,0001$ that mean, there were a difference in effectivity between Leucaena's leaves and Jatropha's leaves to burn grade II healing process with a difference of 2 days, Leucaena's leaves was faster. Thus, Leucaena's leaves was more effective in healing burn grade II, seen from substance, adaptation to environment, processing, efficiency, affordability and availability in the community, so it can be use as a complementary therapy.
\end{abstract}

Keyword: Effectivity, Leucaena leucocephala, Jatropha curcas, The Healing Burn of Grade II

Jurnal IImu Keperawatan, Vol: 4 No. 1, Mei 2016; Korespondensi : Siti Ni'matur Rohmah STIKES Karya Husada Kediri, Jalan Soekarno Hatta No. 7 Pare - Kediri, Jawa Timur .Email :nikmatrhmh@gmail.com 


\section{PENDAHULUAN}

Luka bakar derajat dua adalah luka bakar yang meliputi destruksi epidermis serta lapisan atas dermis dan cedera pada bagian dermis yang lebih dalam. Luka bakar derajat dua yang kerusakannya mengenai bagian superfisial dari dermis termasuk derajat dua dalam dimana penyembuhan terjadi secara spontan dalam waktu sekitar 21 hari dengan jaringan parut minimal (Smeltzer \& Suzanne, 2002).

Menurut World Health Organization (WHO) prevalensi luka bakar menyebabkan 195.000 kematian tahun hingga 2012 diseluruh dunia terutama di negara miskin dan berkembang seperti wanita di ASEAN memiliki tingkat terkena luka bakar lebih tinggi dari wilayah lainnya, dimana $27 \%$ nya berkontribusi menyebabkan kematian diseluruh dunia, dan hampir $70 \%$ nya merupakan penyebab kematian di Asia Tenggara (Rahmi, 2012 dalam Erlinda, 2014).Prevalensi kejadian luka bakar di Indonesia sebesar 2,2\%. Prevalensi tertinggi terdapat di provinsi Nangroe Aceh Darussalam dan Kepulauan Riau sebesar 3,8\%. Menurut kelompok umur, prevalensi luka bakar paling banyak dijumpai pada kelompok umur di bawah satu tahun/bayi (3,3\%) (Riskesdas, 2008 dalam Amri, 2015). Berdasarkan data prevalensi luka bakar di Jawa Timur sebesar $0,7 \%$. Prevalensi tertinggi terjadi pada anak usia 1-4 tahun sebesar 1,5\% (Balitbang Kemenkes $\mathrm{RI}, 2013)$.
Luka bakar disebabkan oleh pengalihan energi dari suatu sumber panas ke tubuh. Panas dapat dipindahkan lewat hantaran atau radiasi elektromagnetik. Luka bakar dapat dikelompokkan menjadi luka bakar termal, radiasi atau kimia. Destruksi jaringan terjadi akibat koagulasi, denaturasi protein atau ionisasi sel. Kulit dan mukosa saluran nafas atas merupakan lokasi destruksi jaringan. Jaringan yang dalam termasuk organ viseral dapat mengalami kerusakan karena luka bakar elektrik atau kontak yang lama dengan burning agent. Dalamnya luka bakar tergantung pada suhu agen penyebab luka bakar dan lamanya kontak dengan agen tersebut (Moenadjat, 2003).

Luka bakar yang tidak segera di atasi dapat menimbulkan komplikasi infeksi antara lain: infeksi respirasi (24\%), infeksi ginjal (15\%), infeksi kardiovaskuler (16\%), infeksi hematologi (1\%), dan infeksi neurologi (1\%). Luka bakar memiliki klasifikasi berdasarkan kedalaman luka dan luas luka, antara lain: luka bakar derajad I, derajad II, dan derajad III. Luka bakar derajad III merupakan luka yang paling luas dan merusak seluruh lapisan kulit. Salah satu faktor yang mempengaruhi mortalitas pada luka bakar adalah luas luka bakar yaitu $\geq 50 \%$ Total Body Surface (TBSA) (Moenadjat, 2009). Proses penyembuhan luka merupakan suatu hubungan yang kompleks antara aksi seluler dan biokimia yang akan mengawali proses pemulihan www.jik.ub.ac.id 
integritas struktural dan fungsional dengan menumbuhkan kembali kekuatan pada jaringan yang terluka tersebut meliputi interaksi sel-sel berkelanjutan dan sel-sel matriks yang menyebabkan terjadinya proses inflamasi, kontraksi luka, re-epitelisasi, maturasi atau remodeling jaringan, dan pembentukan jaringan granulasi dengan angiogenesis (Potter \& Perry, 2005).

Infeksi pada luka bakar sangat memerlukan perawatan yang efektif. Perawatan terbaik dan optimal dalam penanganan luka ini adalah dengan menggunakan bahan dan metode yang dapat mempercepat kontraksi luka, mencegah terbentuknya jaringan granulasi yang berlebihan, mencegah pertumbuhan bakteri, mampu mempertahankan $\mathrm{pH}$ normal dan sebagai pelembab yang sesuai untuk mempercepat penutupan luka (Thomas, 2005 dalam Rohmawati, 2008). Banyak sekali metode yang dapat diterapkan dalam proses penyembuhan luka bakar, salah satunya adalah penelitian tentang uji ekstrak daun petai cina yang memberikan efek antiinflamasi pada luka sayat mencit jantan (Mus musculus) yang diteliti oleh (Amirah dkk, 2014) dan ekstrak daun jarak pagar yang memberikan efek antiinflamasi akut terhadap tikus putih yang diteliti oleh (Anggriani, 2008).

Ada beberapa alternatif terapi komplementer luka bakar grade /l yaitu dengan bobok daun petai cina dan daun jarak pagar. Penggunaan terapi ini lebih efektif karena tidak mengurangi kandungan yang ada di dalam daun petai cina maupun daun jarak pagar serta dapat di minimalisir efek sampingnya sedangkan pada pengekstrakan melewati beberapa proses salah satunya proses pengeringan yang mana dalam proses ini dilakukan pemanasan dengan menggunakan suhu tinggi agar didapatkan ekstrak tanaman. Proses pengeringan dengan metode pemanasan dapat mengurangi kandungannya serta dalam proses pengekstrakan biasanya dicampur dengan bahan lain seperti etanol. Yang mana apabila ada proses pencampuran dengan bahan lain juga akan mempengaruhi efektif atau tidaknya pengobatan herbal yang digunakan (Tirtajaya dkk, 2014).

Beberapa penelitian menyebutkan bahwa daun petai cina mengandung zat aktif alkaloid, saponin, flavonoid, lektin dan tanin. Berbagai kandungan yang terdapat dalam daun petai cina diperkirakan sebagai antiinflamasi dan antioksidan adalah flavonoid. Sementara lektin berfungsi menstimulasi pertumbuhan sel kulit, alkaloid berfungsi sebagai antimikroba. Saponin dapat mempercepat penyembuhan luka karena memacu pembentukan kolagen dengan adanya protein (Priosoeryanto, 2006 dalam Rahmawati, 2014). Senyawa tanin berfungsi sebagai adstringen yang dapat menciutkan pori-pori kulit membentuk jaringan baru dan Jurnal IImu Keperawatan - Volume 4, No. 1 Mei 2016 
antibakteri (Simon dan Kerry, 2000 dalam Muntiaha, 2014). Sedangkan daun jarak pagar mengandung fenol, terpenoid, flavonoid, saponin (Oskoueian dkk, 2011 dalam Pratama dkk, 2014) dan alkaloid (Gupta dkk, 2011 dalam Pratama dkk, 2014). Cara kerja flavonoid untuk efekantiinflamasi(Robinson, 2006 dalam Anggriani, 2008). Igbinosa dkk dalam menyebutkan bahwa kandungan saponin berperan dalam antiseptik dan merangsang pertumbuhan sel-sel baru (Napanggala, 2014). Terpenoid diketahui mempunyai efek antimikroba, dan antioksidan yang kuat diduga bertanggungjawab dalam kontraksi luka dan peningkatan kecepatan dari epitelisasi(Saroja dkk, 2012 dalam Wijaya, 2014).

Dari hasil studi yang sudah dilakukan oleh peneliti sebelumnya, menunjukkan bahwa daun petai cina dan daun jarak pagar terbukti dapat mempercepat proses penyembuhan luka sayat pada mencit jantan (Mus musculus). Maka peneliti saat ini ingin membandingkan efektivitas daun petai cina (Leucaena leucocephala) dan daun jarak pagar (Jatropha curcas) pada proses penyembuhan luka bakar grade II pada tikus putih (Rattus norvegicus) karena merupakan salah satu hewan percobaan yang memiliki struktur anatomi, fisiologi, dan histologi organ yang secara sistematis hampir sama dengan organ manusia.

Hasil penelitian ini dapat menambah ilmu dan sebagai informasi ilmiah tentangEfektivitas Daun Petai Cina (Leucaena leucocephala) dan
Daun Jarak Pagar (Jatropha curcas) Terhadap Proses Penyembuhan Luka Bakar Grade I/ Pada Tikus Putih (Rattus norvegicus).Dan penelitian ini diharapkan dapat menciptakan produk berupa sediaan topikal dari daun petai cina maupun daun jarak pagar yang bisa digunakan masyarakat untuk pengobatan yang lebih aman, praktis, mudah dengan harga terjangkau.

\section{BAHAN DAN METODE}

Penelitian ini menggunakan desain penelitian True Eksperimental Design dengan rancangan penelitian Comparative Design yang dilaksanakan dengan menggunakan hewan coba tikus putih (Rattus norvegicus), untuk mengetahui efektivitas daun petai cina (Leucaena leucocephala) dan daun jarak pagar (Jatropha curcas) terhadap proses penyembuhan luka bakar grade II pada tikus putih (Rattus norvegicus).Penelitian dilakukan di Laboratorium Biomedik STIKES Karya Husada Kediri pada tanggal 12 Februari - 12 Maret 2016

Yang digunakan sebagai sampel dalam penelitian ini adalah tikus putih (Rattus norvegicus). Hewan coba ini dilakukan pembuatan luka bakar, dengan kriteria: jenis kelamin jantan, sehat, umur 3 bulan, jenis tikus putih sama dan berat badan 300-350 gram. Semua hewan coba ditempatkan pada kandang yang terbuat dari baskom dengan ukuran $55 \times 35 \times 15 \mathrm{~cm}$ untuk penutupnya menggunakan kawat berjari-jari yang sudah dipotong sesuai 
ukuran, serta alasnya diberi serabut kayu. Selama penelitian diberikan nutrisi yang sama, dengan memperhatikan kondisi kebersihan dari tempat makanan maupun minuman, selain itu ruangan selalu dalam kondisi kering, kebisingan terjaga karena berada didalam area ruangan kampus.

Sampel dilakukan pembagian menjadi dua kelompok, yaitu satu kelompok dengan perlakuan daun petai cina dan satu lainnya dengan daun jarak pagar. Pembagian kelompok ini dengan caraRandom Sampling.Dalam penelitian ini didapatkan jumlah sampel tiap kelompok perlakuan sebanyak 9 ekor ditambah 3 ekor sebagai cadangan.

Variabel independen dalam penelitian ini adalah perawatan dengan menggunakan lumatan daun petai cina 10 gram dan lumatan daun jarak pagar 10 gram. Sedangkan variabel dependennya adalah proses penyembuhan luka bakar grade II .

Langkah pertama yang dilakukan adalah pembuatan luka bakar derajad II dalam pada sampel yang kemudian dilakukan pemberian perlakuan sesuai dengan rencana penelitian hanya pada dua kelompok perlakuan.Pada tahap penelitian, sampel dilakukan penilaian dengan observasi menggunakan lembar observasi sampai pada fase awal maturasi (luka mengecil, ada/tidaknya jaringan parut, terdapat garis putih). Penilaian lama penyembuhan luka bakar derajad II dalam dilakukan setiap pagi jam 09.00 WIB selama 30 hari. Penelitian ini telah mendapatkan persetujuan dari Komite Etika Penelitian STIKes Karya Husada Kediri pada tanggal 22 Januari 2016 dengan No. 227/KEP/I/2016.

Analisa yang digunakan dalam penelitian ini adalah Parametric Test yaitu Independent t-test dengan skala ukur rasio dengan selang kepercayaan 99\% $(\alpha=0,01)$. Jika telah didapatkan hasil, kita bandingkan pvalue dengan $\alpha \leq 0,01$ untuk menentukan apakah ada pengaruh antara variabel independen terhadap variabel dependen yang diteliti.

\section{HASIL}

Setelah dilakukan percobaan pada 18 ekor tikus putih (Rattus norvegicus) selama 30 hari dengan perlakuan berupa perawatan luka bakar derajad II dalam dengan menggunakan bahan yang berbeda didapatkan hasil sebagai berikut:

Proses penyembuhan luka bakar G.II bobok daun petai cina

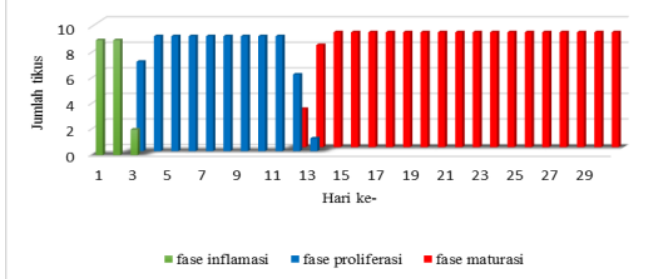

Gambar 1 : Hasil identifikasi proses penyembuhan luka bakar derajad II dalam pada kelompok perlakuan lumatan daun petai cina.

Berdasarkan diagram batang di atas diketahui bahwa observasi dilakukan selama 30 hari dengan jumlah 9 ekor tikus putih. Pada hari pertama seluruh tikus (100\%) mengalami fase inflamasi, hari ke-3 tujuh ekor tikus putih 
$(77,78 \%)$ mengalami fase proliferasi, hari ke-12 tiga ekor tikus putih $(33,33 \%)$ mulai memasuki fase maturasi, hari ke-13 delapan ekor tikus putih $(88,89 \%)$ memasuki fase maturasi, hari ke-14 semua tikus putih (100\%) sudah memasuki fase maturasi sampai observasi hari ke-30.

Proses penyembuhan luka bakar G.II bobok daun jarak pagar

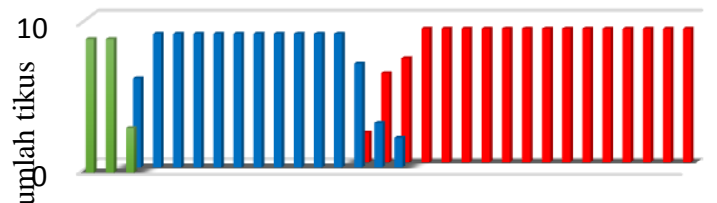

$\begin{array}{llllllllllll}1 & 3 & 5 & 7 & 9 & 11 & 13 \text { PIF } 1921232527 & 19\end{array}$

$\square$ fase inflamasi $\square$ fase proliferasi $\square$ fase maturasi

Gambar 2 : Hasil identifikasi proses penyembuhan luka bakar derajad II dalam pada kelompok perlakuan lumatan daun jarak pagar.

Berdasarkan diagram batang di atas diketahui bahwa observasi dilakukan selama 30 hari dengan jumlah 9 ekor tikus putih. Pada hari pertama seluruh tikus (100\%) mengalami fase inflamasi, hari ke-3 enam ekor tikus putih $(66,67 \%)$ mengalami fase proliferasi, dan hari ke-14 dua ekor tikus putih (22,22\%) mulai memasuki fase maturasi, hari ke-15 enam ekor tikus putih $(66,67 \%)$ memasuki fase maturasi, hari ke-16 tujuh ekor tikus putih (77,78\%) memasuki fase maturasi dan hari ke-17 semua tikus putih (100\%) sudah memasuki fase maturasi sampai pada observasi hari ke-30.

Normalitas data diuji menggunakan Levene statistics didapatkan nilai signifikan $(\rho)=0,137$ $>\alpha=0,01$, yang ditunjukkan dalam tabel 1 . sehingga dapat disimpulkan bahwa distribusi data normal dan homogen serta memenuhi syarat untuk dilanjutkan ke uji parametrik Independent t-test dengan skala ukur rasio.

Tabel 1. Hasil Hasil Uji Normalitas dan Homogenitas Levene Test

\begin{tabular}{|c|c|c|}
\hline $\begin{array}{l}\text { Kelompok } \\
\text { Perlakuan }\end{array}$ & $\mathbf{N}$ & $\begin{array}{c}\text { Mea } \\
n\end{array}$ \\
\hline
\end{tabular}

(Sig.)

\begin{tabular}{lllll}
\hline $\begin{array}{l}\text { Lama } \\
\begin{array}{l}\text { Penyembu } \\
\text { han (hari) }\end{array}\end{array}$ & $\begin{array}{l}\text { Bobok daun } \\
\text { petai cina }\end{array}$ & 9 & 12,78 & 0,137 \\
& $\begin{array}{l}\text { Bobok daun } \\
\text { jarak pagar }\end{array}$ & 15,33 & \\
& & & \\
\hline
\end{tabular}

Tabel 2. Hasil Analisa Data dengan uji parametrik Independent t-test

\begin{tabular}{lllccc}
\hline & $\begin{array}{l}\text { Kelompok } \\
\text { Perlakuan }\end{array}$ & N & Mean & $\begin{array}{c}\text { Std. } \\
\text { Deviasi }\end{array}$ & Pvalue \\
\hline Lama & $\begin{array}{l}\text { Bobok } \\
\text { Penye } \\
\text { daun petai }\end{array}$ & 9 & 12,78 & 0,667 & $\rho<$ \\
nbuha & cina & & & & 0,0001 \\
& $\begin{array}{l}\text { Bobok } \\
\text { daun jarak } \\
\text { pagar }\end{array}$ & 9 & 15,33 & 1,118 & $\rho<$ \\
& & & & 0,0001 \\
\hline & & & & & $\alpha=0,01$
\end{tabular}

Berdasarkan hasil uji Independent t-test denganskala rasio,menunjukkan bahwa rata-rata penyembuhan menggunakan bobok daun petai cina $=12,78$ hari $=13$ hari, sedangkan rata-rata penyembuhan menggunakan bobok daun jarak pagar $=15,33$ hari $=15$ hari. Hasil uji Independent t-test menunjukkan signifikan $(\rho)=0,0001<\alpha=$ $0,01, \rho<\alpha$ maka H1 diterima berarti ada perbedaan antara lumatan daun petai cina dan lumatan daun jarak pagar terhadap luka bakar derajad II dalam yang menunjukkan selisih 2 hari. 


\section{PEMBAHASAN}

\section{a. Proses penyembuhan Luka Bakar Derajad II} Dalam pada Kelompok Perlakuan Bobok

\section{Daun Petai Cina}

Berdasarkan analisa statistika menunjukkan rata-rata fase maturasi (penyembuhan) yaitu 12,78 dengan lama penyembuhan terbanyak pada hari ke-13. Hasil ini dikarenakan daun petai cina (Leucaena leucocephala) mempunyai sifat-sifat yang sangat menguntungkan dan sangat bagus untuk perawatan luka. Dari berbagai literatur disebutkan bahwa penggunaan daun petai cina dapat mempercepat proses penyembuhan luka seperti pada luka sayat dan luka bersih yang pernah diteliti oleh (Amirah dkk, 2014; Rahmawati, 2014). Mengutip para ilmuwan sebelumnya, kemampuan menyembuhkan luka diduga karena Alkaloid, Saponin, Flavonoid, Lektin, dan Tanin.

Pada tahap pertama penyembuhan luka ada proses inflamasi yang terjadi selama 0-4 hari. Dalam fase inflamasi ini, benda-benda asing khususnya bakteri dapat menimbulkan peradangan persisten dan memperlambat penyembuhan luka (Rahmawati, 2014). Salah satu kandungan daun petai cina yaitu Alkaloid sebesar 11,2\% mempunyai daya antiseptik yaitu mencegah kerusakan yang disebabkan oleh bakteri atau jamur. Untuk menghilangkan nyeri yang biasa timbul selama proses peradangan daun petai cina juga memiliki kandungan Flavonoid sebesar $12,5 \%$ yang berfungsi sebagai analgesik. Selain sebagai analgesik, Flavonoid berfungsi sebagai agen dalam mencegah inflamasi dan menangkap serta menetralkan radikal bebas seperti ROS (reactive oxygen species) yang terkait dengan gugus $\mathrm{OH}$ fenolik sehingga dapat memperbaiki keadaaan jaringan yang rusak dengan kata lain proses inflamasi dapat terhambat (Febriyanti, 2015). Pada tahap pembentukan jaringan granulasi tampak pembuluh darah baru yang mengandung granula dari jaringan yang dibakar. Daun petai cina terdapat kandungan Saponin 6,74\%, Lektin 7,92\%, dan Tanin 13,34\% yang berfungsi meningkatkan pembentukan pembuluh darah baru dan memacu pembentukan kolagen dengan adanya protein sehingga dapat mempercepat proses penyembuhan luka. Selain itu daun petai cina dapat mengurangi timbulnya jaringan parut atau bekas luka pada kulit (Qomariah, 2014).

Seperti halnya dengan penelitian ini, kelompok perlakuan yang diberikan lumatan daun petai cina juga mengalami proses peradangan, yang terjadi rata-rata pada hari ke-1, hal ini terjadi karena proses dari penyembuhan luka itu sendiri. Penyembuhan luka merupakan respon dasar terhadap luka jaringan yang menyebabkan pemulihan integritas kulit (Dewi, 2014). Dari proses biologik utama dalam perbaikan Jurnal IImu Keperawatan - Volume 4, No. 1 Mei 2016 
jaringan ada tahap-tahap antara lain eritema dan pembentukan jaringan granulasi.

Eritema sendiri dapat diartikan sebagai peradangan, sedangkan istilah granulasi berasal dari pengamatan patologi makro bahwa pada waktu jaringan tersebut di insisi, terlihat banyak sekali mangandung granula atau serabut berwarna putih yang sebenarnya merupakan pembuluh darah yang baru dibentuk (Dewi, 2014).

Berdasarkan fakta dan teori di atas, proses penyembuhan luka bakar derajad II dalam menurut teori inflamasi (luka merah, hangat, bengkak) dimulai setelah beberapa menit dan berlangsung selama 4-5 hari setelah cedera, fase proliferasi (tertutup jaringan granulasi, merah muda) terjadi dalam waktu 5-21 hari dan fase maturasi selama $\geq 21$ hari bahkan sampai 1-2 tahun (Potter \& Perry, 2005) dan pada hasil penelitian diketahui bahwa proses penyembuhan luka bakar derajad II dalam pada kelompok perawatan daun petai cina fase inflamasi (luka merah, bengkak, hangat) terjadi dalam waktu 1-3 hari, fase proliferasi (tertutup jaringan fibrin, berwarna merah muda) terjadi dalam waktu 3-12 hari dan fase maturasi terjadi dalam waktu 12-14 hari. Hal ini karena kandungan yang terdapat pada daun petai cina seperti Flavonoid, Alkaloid, Tanin, Saponin, dan
Lektin yang dapat membantu penyembuhan luka.

Flavonoid berfungsi sebagai antiinflamasi dan antioksidan yang menekan efek peradangan, selain itu Flavonoid membantu mengurangi rasa sakit (analgesik). Lektin, Saponin, Tanin berfungsi dalam membantu regenerasi kulit atau menstimulasi pembentukan sel-sel baru yaitu dengan menghambat produksi jaringan luka yang berlebihan, sedangkan Alkaloid berfungsi sebagai antiseptik. Selain itu proses penyembuhan luka yang dipengaruhi beberapa faktor antara lain usia, nutrisi, oksigenasi, infeksi, sirkulasi,dan steroid. Namun dalam penelitian ini, faktor-faktor tersebut telah dikontrol oleh peneliti sehingga memungkinkan proses penyembuhan luka menjadi lebih singkat.

Berdasarkan pembahasan di atas, dapat diketahui bahwa proses penyembuhan infeksi kulit juga dipengaruhi oleh keadaan fisiologis dari hewan uji, karena kulit merupakan barier fisik yang dapat mempertahankan tubuh dengan proses imunologik yang cepat terhadap agen patogen tersebut dan mengeluarkan mikroorganisme tersebut dari epidermis dan dermis.

b. Proses penyembuhan Luka Bakar Derajad II Dalam pada Kelompok Perlakuan Bobok Daun Jarak Pagar 
Penyembuhan luka bakar derajad II dalam pada perawatan luka menggunakan daun jarak pagar menunjukkan rata-rata fase maturasi (penyembuhan) yaitu 15,33 dengan lama penyembuhan terbanyak pada hari ke15.

Beberapa literatur menyebutkan bahwa daun jarak pagar berfungsi sebagai obat luka dan perdarahan. Proses penyembuhan luka bakar derajad II dalam pada punggung tikus putih karena adanya kandungan senyawa Fenol $12,34 \%$ yang berfungsi sebagai antibakteri dan antiseptik. Fenol yang berfungsi sebagai antibakteri maupun antiseptik dengan cara mengikat protein bakteri sehingga menghambat aktivitas enzim yang pada akhirnya mengganggu proses metabolisme bakteri dan mengakibatkan kematian pada bakteri (Baroroh, 2013 \& Anggriani, 2008).

Diketahui bahwa jarak pagar dapat merangsang lendir oleh sebab itu diduga luka yang diobati dengan tanaman jarak pagar terbentuk jaringan granulasi sehingga permukaan luka yang telah sembuh terbentuk sempurna seperti semula.Epitel permukaan luka di bagian tepi mulai melakukan regenerasi, selanjutnya epitel yang tipis bermigrasi ke atas permukaan luka.Jaringan di bawah keropeng menjadi sempurna sehingga terbentuk kembali permukaan kulit (Wahono, 2012). Didalam daun jarak pagar juga mengandung senyawa Saponin $7,85 \%$ dan Terpenoid $10,47 \%$ yang berfungsi untuk menstimulasi fibroblas dalam peningkatan epitelisasi. Saponin merupakan senyawa aktif permukaan yang dihasilkan dari grup steroid atau triterpen yang berikatan dengan gula, senyawa ini memiliki pengaruh biologis yang menguntungkan yaitu bersifat sebagai hipokolesterolemik dan antikarsinogen serta dapat meningkatkan sistem imun.Didalam daun jarak pagar juga terdapat senyawa Flavonoid $6,45 \%$ yang berfungsi sebagai agen antiinflamasi dan antioksidan yang berperan dalam mengikat ROS (reactive oxygen species) atau efek radikal bebas. Selain Flavonoid, didalam daun jarak pagar juga mengandung senyawa Alkaloid yang biasa disebut Jatrophine 5,6\%, yang mana Jatrophine ini bisa digunakan sebagai obat luka.Daun jarak ini bersifat antimikroba sehingga dapat menghilangkan bakteri seperti jenis Staphylococcus, streptococcus, dan Escherichia coli.Alkaloid pada daun jarak ini adalah suatu golongan senyawa organic yang terbanyak ditemukan di alam.Golongan Alkaloid adalah golongan senyawa yang mempunyai struktur heterosiklik dan mengandung atom $\mathrm{N}$ di dalam intinya (pembawa sifat basa atau alkalis).Sifat umum yang dimiliki oleh golongan senyawa ini adalah basa, rasa pahit, umumnya berasal 
dari tumbuhan dan berkhasiat secara farmakologis.

Berdasarkan fakta dan teori di atas, proses penyembuhan luka bakar derajad II dalam menurut teori inflamasi (luka merah, hangat, bengkak) dimulai setelah beberapa menit dan berlangsung selama 4-5 hari setelah cedera, fase proliferasi (tertutup jaringan granulasi, merah muda) terjadi dalam waktu 5-21 hari dan fase maturasi selama $\geq 21$ hari bahkan sampai 1-2 tahun (Potter \& Perry, 2005) dan pada hasil penelitian diketahui bahwa proses penyembuhan luka bakar derajad II dalam pada kelompok perawatan daun petai cina fase inflamasi (luka merah, bengkak, hangat) terjadi dalam waktu 1-3 hari, fase proliferasi (tertutup jaringan fibrin, berwarna merah muda) terjadi dalam waktu 3-14 hari dan fase maturasi terjadi dalam waktu 14-17 hari. Hal ini karena kandungan yang terdapat pada daun petai cina seperti Flavonoid, Alkaloid, Saponin, Terpenoid dan Fenol yang dapat membantu penyembuhan luka.

Flavonoid berfungsi sebagai antiinflamasi dan antioksidan yang menekan efek peradangan, selain itu Flavonoid membantu mengurangi rasa sakit (analgesik).Saponin dan Terpenoid berfungsi dalam menstimulasi pembentukan sel-sel baru yaitu dengan menghambat produksi jaringan luka yang berlebihan, sedangkan Alkaloid dan Fenol yang berperan dalam membunuh mikroorganisme penghambat kesembuhan. Selain itu proses penyembuhan luka yang dipengaruhi beberapa faktor antara lain usia, nutrisi, oksigenasi, infeksi, sirkulasi,dan steroid. Namun dalam penelitian ini, faktorfaktor tersebut telah dikontrol oleh peneliti sehingga memungkinkan proses penyembuhan luka menjadi lebih singkat.

c. Efektivitas Daun Petai Cina (Leucaena leucocephala) Dan Daun Jarak Pagar (Jatropha curcas) Terhadap Proses Penyembuhan Luka Bakar Grade II Pada Tikus Putih (Rattus norvegicus).

Berdasarkan hasil penelitian menunjukkan bahwa ada perbedaan antara daun petai cina (Leucaena leucocephala) dan daun jarak pagar (Jatropha curcas) terhadap proses penyembuhan luka bakar derajad II dalam pada tikus putih (Rattus norvegicus). Hal ini dibuktikan lama fase maturasi (penyembuhan) dari masing-masing kelompok, diperoleh rata-rata fase maturasi pada perawatan daun petai cina 12,78 dengan lama penyembuhan terbanyak pada hari ke-13, sedangkan rata-rata fase maturasi pada perawatan daun jarak pagar 15,33 dengan lama penyembuhan terbanyak pada hari ke-15. Hal ini sesuai dengan hasil penelitian sebelumnya tentang besaran kandungan dari masing-masing daun dikarenakan cepatnya proses epitelisasi 
pada daun petai cina yang memiliki Saponin, Lektin, dan Tanin yang sekaligus berfungsi sebagai senyawa kimia yang memacu pembentukan kolagen, yaitu protein struktur yang berperan dalam proses penyembuhan luka sekaligus mempunyai kemampuan sebagai pembersih sehingga efektif untuk penyembuh luka terbuka. Tanin adalah polifenol tanaman yang berfungsi mengikat dan mengendapkan protein.Dalam dunia pengobatan, Tanin berfungsi untuk menghentikan pendarahan, polifenol ini berperan sebagai antikanker, antioksidan, dan antimikroba. Lektin adalah protein mengikat seltubuh pada glikoprotein dan glikolipid yang terekspresi pada permukaan sel, khususnya pada molekul glukosanya dan memiliki kemampuan untuk membuat sel tersebut menggumpal. Sedangkan didalam daun jarak pagar dalam proses regenerasi sel kulitnya memiliki Saponin dan golongan Terpenoid yang mana berfungsi merangsang pembentukan matriks ekstraseluler, meningkatkan prosentase kolagen dalam sel fibronectin sehingga terjadi percepatan waktu penyembuhan luka bakar. Sementara itu, kandungan dari masing-masing senyawa tersebut memiliki prosentase yang berbeda.Prosentase lebih besar terdapat pada daun petai cina. Efektivitas adalah sesuatu yang memiliki pengaruh atau akibat yang ditimbulkan, manjur, membawa hasil dan merupakan keberhasilan dari suatu usaha atau tindakan. Jadi efektivitas berarti ketercapaian atau keberhasilan suatu tujuan sesuai dengan rencana dan kebutuhan yang diperlukan, baik dalam penggunaan data, sarana maupun waktunya (Abdurahmat, 2003).

Berdasarkan pemaparan hasil penelitian di atas dapat diketahui bahwa daun petai cina (Leucaena leucocephala) lebih efektif digunakan sebagai alternatif penyembuhan luka bakar dari pada daun jarak pagar (Jatropha curcas). Hal ini dapat dilihat pada diagram batang pada masing-masing intervensi. Dari perbandingan cepatnya kesembuhan luka daun petai cina (Leucaena leucocephala), lebih cepat 2 hari dari pada daun jarak pagar (Jatropha curcas). Selain dari efektifnya dalam penyembuhan luka bakar, daun petai cina (Leucaena leucocephala) juga lebih mudah dijangkau dari pada daun jarak pagar (Jatropha curcas).Seperti yang kita ketahui bahwa ketersediaan daun petai cina jauh lebih banyak dari pada daun jarak pagar.Hal ini dipengaruhi oleh kemampuan adaptasi yang dimiliki pohon petai cina lebih baik, sehingga pohon petai cina mampu tumbuh subur. Berbeda dengan pohon jarak pagar yang sedikit sulit tumbuh di berbagai lingkungan, apalagi pohon jarak pagar memiliki banyak hama berupa ulat yang sering memakan daun tanaman jarak pagar.

Jurnal Ilmu Keperawatan - Volume 4, No. 1 Mei 2016 
Dilihat dari segi pengolahan sebagai suatu alternatif penyembuhan luka bakar.Daun jarak pagar terhitung lebih sulit hal ini disebabkan karena daun jarak pagar memiliki serat daun yang lebih kuat sehingga lebih sulit dihaluskan.Sedangkan pada daun petai cina lebih mudah untuk dihaluskan.Satu lagi kekurangan yang dimiliki oleh daun jarak pagar yaitu sulit untuk menempel pada luka, sedangkan pada lumatan daun petai cina mudah menempel dan sulit lepas.

Memang ketersediaan untuk daun jarak pagar di masyarakat masih jarang tetapi untuk masyarakat yang segera membutuhkan pertolongan dalam penanganan luka seperti luka bakar, daun jarak pagar mudah untuk dijangkau, hanya tinggal memetik dari pohonnya tanpa kita harus mengambil galah untuk mengambilnya.Dan juga masyarakat kini tidak hanya menggunakan daun jarak pagar sebagai obat luka sayat tetapi juga sebagai obat sakit perut (kembung) terutama pada anak-anak yang mudah dilakukan, hanya tinggal ditempel pada bagian luar perut.Seperti dilansir daun jarak pagar juga di gunakan di desa Trunyan yang merupakan salah satu desa terpencil di Bali yang terletak di kecamatan Kintamani Kabupaten Bangli tepatnya disebelah timur Danau Batur sebagai salah satu tanaman obat-obatan tradisional (Sudirga, 2015). Bagian tumbuhan yang paling banyak digunakan sebagai bahan obat tradisional disana adalah bagian daun (46,21\%). Daun jarak pagar di desa Trunyan digunakan dalam pengobatan luka bakar. Pemanfaatannya juga sangat sederhana, daun di cuci bersih dan di tumbuk kemudian ditempelkan pada bagian luka, disana cara ini relatif cepat mengingat tempat layanan kesehatan seperti puskesmas masih sangat terbatas (Sudirga, 2015).

Kedua variabel tersebut dapat mempengaruhi luka bakar, karena dapat meminimalisir komplikasi yang berakibat infeksi seperti infeksi respirasi (24\%), infeksi ginjal (15\%), infeksi kardiovaskuler (16\%), infeksi hematologi (1\%), dan infeksi neurologi (1\%).Upaya tersebut adalah sebagai pertolongan pertama saat insiden terjadi.Dalam bidang keperawatan kedua variabel dapat dijadikan sebuah intervensi perawatan komplementer yang dapat diterapkan dalam keperawatan homecare.Bagi masyarakat sendiri kedua variabel dapat dijadikan sebuah intervensi alternatif yang nantinya dapat diterapkan oleh masyarakat sendiri dalam menanggulangi insiden luka bakar.

Dengan demikian, daun petai cina lebih efektif dalam penyembuhan luka bakar derajad II dalam,dilihat dari kandungan, 
adaptasi tumbuhan terhadap lingkungan, pengolahan, efisiensi, keterjangkauan dan ketersediaan di masyarakat, sehingga dapat dimanfaatkan sebagai salah satu terapi komplementer.

\section{KESIMPULAN}

Hasil penelitian menunjukkan bahwa Proses penyembuhan (fase maturasi) luka bakar grade Il dengan menggunakan bobok daun petai cina 10 gram, rata-rata penyembuhan sebesar 12,78 dengan lama penyembuhan terbanyak pada hari ke-13. Proses penyembuhan (fase

\section{DAFTAR PUSTAKA}

Abdurahmat.2003. Pengertian Tentang Efektivitas, (Online), http://othenk.blogspot.com/2008 200 8 11 01 achive.html, diakses tanggal 09 April 2016.

Anggriani, N. 2008.Uji Efek Antiinflamasi Akut Ekstrak Daun Jarak Pagar (Jatropha curcas L.) Pada Tikus Putih. Skripsi. Fakultas Farmasi, Universitas Katolik Widya Mandala, Surabaya.

Amirah, S., R. Kosman \& R. N. Y. 2014. Uji Efek Anti-Inflamasi Ekstrak N-Butanol Dan Etil Asetat Daun Petai Cina (Leucaena Leucocephala (Lamk.)De Wit) Pada Mencit Jantan (Mus Musculus) Yang Diinduksi Dengan Karagen.Bionature Journal 15 (2).

Amri, Dwi Y. Efektivitas Krim Ekstrak Kunyit (Curcuma Domestica Valet) Terhadap Penyembuhan Luka Bakar Pada Tikus Putih (Rattus norvegicus), (Online), http://www.dokumen.tips/documents/y 55721316497959fc0b91932d.html, diakses 03 Oktober 2015

Baroroh, H. N., and E. P. N. Rachmani.2013. maturasi) luka bakar grade II dengan menggunakan bobok daun jarak pagar 10 gram, rata-rata penyembuhan sebesar 15,33 dengan lama penyembuhan terbanyak pada hari ke-15. Perawatan luka bakar grade II dengan menggunakan bobok daun petai cina 2 hari lebih efektif dibandingkan bobok daun jarak pagar. Hasil penelitian ini hendaknya dapat digunakan sebagai alternatif pengobatan dalam masyarakat yang bukan hanya untuk obat luka abrasi maupun luka sayat, tetapi juga untuk luka bakar.

Ketoksikan Akut dari Ekstrak Etanolik Daun Jarak Pagar (Jatropa curcas) pada Mencit Jantan Galur Balb/C. Jurnal Natur Indonesia 15 (1).

Dewi, Christina. 2014. Perbedaan Efek Perawatan Luka Dengan Menggunakan Getah Pohon Yodium Dibandingkan Dengan Menggunakan Povidon lodine 10\% Dalam Mempercepat Penyembuhan Luka Bersih Pada Marmut (Cavia porcellus). Jurnal Wiyata 1 (2).

Erlinda, M. 2014. Asuhan Keperawatan Pada Klien Dengan Luka Bakar Di Instalasi Rawat Inap Khusus Luka Bakar Bangsal Bedah RSUP Dr. M. Djamil Padang, (Online), http://musnierlinda.blogspot.co.id/201 4/09/askep-luka-bakarcombustio.html, diakses tanggal 02 Oktober 2015

Febriyanti, Y. 2015. Pengaruh Ekstrak Metanol Biji Mahoni Terhadap Peningkatan Kadar Insulin Penurunan Ekspresi TNFa Dan Perbaikan Jaringan Pankreas Tikus Diabetes: Kompasiana. 
Moenadjat, Y. 2003. Luka Bakar: Pengetahuan

Klinik Praktis. Jakarta: Balai Penerbit FKUI.

Moenadjat. 2009. Luka Bakar Masalah Dan

Tata Laksana. Jakarta: Balai Penerbit FKUI.

Muntiaha, M. C., P. V. Y. Yamlean \& W. A. Lolo. 2014. Uji Efektivitas Sediaan Krim Getah Jarak Cina (Jatropha multifida L.) Untuk Pengobatan Luka Sayat Yang Terinfeksi Bakteri Staphylococcus aureus Pada Kelinci (Orytologus cuniculus).Jurnal Imiah FarmasiUNSRAT 3 (3).

Napanggala, A., Susianti \& A. E. 2014. Pengaruh Pemberian Getah Tanaman Jarak Pagar (Jatropha curcas L.) Secara Topikal Terhadap Tingkat Kesembuhan Luka Iris Pada Tikus Putih Jantan Galur Sprague Dawley. Medical Journal 3 (5). Rahmawati, I. 2014. Perbedaan Efek Perawatan Luka Menggunakan Gerusan Daun Petai Cina (Leucaena glauca, Benth) Dan Povidon lodine 10\% Dalam Mempercepat Penyembuhan Luka Bersih Pada Marmut (Cavia porcellus). Jurnal Wiyata 1 (2).

Potter \& Perry. 2005. Fundamental Keperawatan: Konsep, Proses, \& Praktik. Edisi 4 Vol. 1. Jakarta: EGC.

Pratama, R. D., Yuliani \& G. T. Mulyono.2014. Efektivitas Ekstrak Daun Dan Biji Jarak Pagar (Jatropha curcas) Sebagai Antibakteri Xanthomonas Campestris Penyebab Penyakit Busuk Hitam Pada
Tanaman Kubis.Jurnal Online Universitas Negeri Surabaya.

Qomariah, Siti. 2014. Efektivitas Salep Ekstrak Batang Patah Tulang (Euphorbia tirucalli) Pada Penyembuhan Luka Sayat Tikus Putih (Rattus norvegicus).Skripsi.Fakultas

Matematika Dan Ilmu Pengetahuan Alam Universitas Negeri Semarang.

Balitbang Kemenkes RI. 2013. Riset Kesehatan Dasar; RISKESDAS. Jakarta: Balitbang Kemenkes RI.

Smeltzer, S. C., and B. G. Bare. 2002. Keperawatan Medikal Bedah: Brunner \& SuddarthVol. 1. Edited by M. Ester and E. Penggabean. Jakarta: EGC.

Tirtajaya, I., D. Sofia, L. Ratnawati \& H. F. Lien. 2004. Pengaruh Suhu Pengeringan Terhadap Komponen Sineol Dalam Daun Kayu Putih. Jurnal IImu dan Teknologi Pangan 2 (2).

Wahono, Bevo. 2012. Potensi Getah Jarak Pagar (Jatropha curcas) Terhadap Proses Penyembuhan Luka Pada Mencit (Mus musculus) Galur Balb C. Tesis. Program Studi Pendidikan Biologi, Program Pascasarjana, Universitas Negeri Malang.

Wijaya, B. A., G. Citraningtyas \& F. Wehantouw.2014. Potensi Ekstrak Etanol Tangkai Daun Talas (Colocasia Esculenta L.) Sebagai Alternatif Obat Luka Pada Kulit Kelinci (Oryctolagus cuniculus). Jurnal IImiah Farmasi 3 (3) 